\title{
Does Body Mass Index Have an Impact on Prostate Volume and Serum Prostate Specific Antigen? A Prospective Observational Study in Patients with Lower Urinary Tract Symptoms
}

\author{
Ashok Kumar Sokhal ${ }^{*}$, Ankur Jhanwar ${ }^{1}$, Satyanarayan Sankhwar ${ }^{1}$, Kawaljit Singh ${ }^{1}$, Ashok \\ Kumar Gupta ${ }^{1}$, Durgesh Kumar Saini ${ }^{1}$, Bimalesh Purkait ${ }^{1}$, Manoj Kumar ${ }^{1}$ \\ ${ }^{1}$ Department of Urology, King George's Medical University, Lucknow, Uttar Pradesh, India
}

Received: October 06, 2016; Accepted: October 17, 2016; Published: October 27, 2016

*Corresponding author: Ashok Kumar Sokhal, Department of Urology, King George's Medical University, Lucknow, Uttar Pradesh, India, Mobile no: 9695845074; E-mail: drashokkumarsokhal@gmail.com

\begin{abstract}
Purpose: To observe the association between Body Mass Index, prostate volume and serum PSA in patients presenting with lower urinary tract symptoms and possible clinical relevance.

Methods: Prospective study between January 2012 to December 2014 including 1100 patients. Participants were consecutive male patients of 40 years of age or older, presenting with LUTS. Comprehensive assessment, including history, physical examination, BMI calculation and serum PSA. Patients with history of TURP, carcinoma prostate, urethral stricture or with a history of any trans urethral procedure were excluded.

Results: All the patients were Indian with a mean age of 58.18 years. The mean serum PSA level had no significant difference across three BMI categories ( $p>0.05)$. Mean PV was gradually larger with increasing BMI value (normal weight 33.02 cc; overweight 36.52 cc; obese $37.75 \mathrm{cc} ; \mathrm{p}<0.001)$. BMI was found to have correlation with PV ( $r s=0.132 ; p<0.001$ ) but not with PSA ( $r s=0.039 ; p 0.191)$ and IPSS ( $\mathrm{rs}=0.013 ; \mathrm{p} 0.760$ ).
\end{abstract}

Conclusions: We establish a positive correlation of BMI with prostate volume among Indian ethnic patients presenting with LUTS. We found no significant association of BMI with serum PSA and IPSS.

Keywords: Benign prostatic hyperplasia; Growth factors; Lower urinary tract symptoms, Metabolic syndrome, Prostate neoplasm, Prostate volume, Prostate carcinoma, Quality of life

\section{Introduction}

Carcinoma prostate is on rising trend since last two decades causing significant morbidity and mortality in Asian countries. Indian registries had revealed rising incidence of prostatic carcinoma with mean percentage change of 0.14-8.6 annually [1]. On the other hand, the incidence and the prevalence of benign prostatic hyperplasia (BPH) also increases with increasing age and leading significant morbidity of urinary tract infection, and/ or vesical calculus, acute urinary retention, acute renal failure and negative impact on quality of life [2-5]. Serum Prostate Specific Antigen (PSA) is a globally used screening tool for carcinoma prostate, based on which prostate biopsy largely recommended when PSA value exceeds $4 \mathrm{ng} / \mathrm{mL}$ [6]. PSA blood level variation had been studied with respect to numerous factors including age, race, prostate volume (PV), androgen level, body mass index (BMI), creatinine, liver enzymes [7], and genetic polymorphisms [8].

India is the leading country in obesity after United States and China, contributing 30 million obese populations globally [9]. Obesity had been associated with higher biochemical and radiation failure after radical prostatectomy, higher Gleason grade in literature [10]. Association between PV, serum PSA and obesity had been investigated in few studies in American [11], East Asia (China, Korea) [12], European [13], having mixed results.

To the author's knowledge, this is the first such kind of study which observes the association between BMI, prostate volume and serum PSA in patients presenting with lower urinary tract symptoms (LUTS) from India representing South Asia region and possible clinical relevance.

\section{Objective}

To assess the impact of body mass index on prostate volume and serum PSA level and explore the possible clinical relevance.

\section{Materials and Method}

We conducted a prospective cross-sectional study in the Department of Urology, at tertiary care centre of North India, between January 2012 to December 2014.Ethical clearance was obtained from institutional review board. Eligible participants were consecutive male patients of 40 years of age or older, presenting with LUTS. All patients underwent a comprehensive assessment, including clinical history, including International 
Prostate Symptom Score (IPSS), physical examination including digital rectal examination (DRE), anthropometry including height, weight and BMI calculation. Patients with a history of trans urethral resection of prostate, carcinoma prostate, urethral stricture or with a history of any trans urethral procedure were excluded from the study. The blood sample was obtained at the first visit for serum PSA determination (chemiluminescent enzyme immunoassay method). Those patients having suspicious finding on DRE or trans rectal ultrasound (TRUS) or PSA > $4 \mathrm{ng} / \mathrm{dl}$ underwent TRUS guided prostate biopsy and excluded if positive for prostatic malignancy. BMI was calculated by dividing the weight in kilograms by the square of the height in meters $(\mathrm{kg} / \mathrm{m} 2)$. Prostate volume $(\mathrm{cm} 3)$ was measured by a single experienced radiologist by TRUS (LOGIQ CS Premium). Participants were categorized as being normal weight (BMI 17.50 to $22.99 \mathrm{~kg} / \mathrm{m} 2$ ), overweight (BMI 23.00 to $27.99 \mathrm{~kg} / \mathrm{m} 2$ ), or obese (BMI $>28.00 \mathrm{~kg} / \mathrm{m} 2$ ) according to the Asian population [14].

\section{Statistical Analysis}

BMI stands as the variable of interest in this study and PSA, $\mathrm{PV}$ as variables for the outcome measure. Continuous data are given as mean \pm SD while discrete (categorical) are presented in percentages. The categorical variables were compared by chisquare $(\chi 2)$ test. Spearman's correlation was used. A two-sided $(\alpha=2) p<0.05$ is considered statistically significant. All statistical analyses were performed using statistical package for Social Sciences, version 16.0 (SPSS, Chicago).

\section{Results}

We conducted a prospective cross-sectional study enrolling 1100 patients during 2012-2014. All the patients were Indian with a mean age of 58.18 years (range; $41-76$ years). The majority of patients were in the range of $55-65$ years. According to BMI, the majority of patients (58\%) were in the overweight group (BMI 23.00-27.99), and $10.82 \%$ were in the obese group with a $\mathrm{BMI}>28.00$. Mean PSA of the study population was $1.93+1.79$ $\mathrm{ng} / \mathrm{ml}$. PSA value was $<4 \mathrm{ng} / \mathrm{ml}$ in 1048 patients $(90.73 \%)$ and rest with PSA $>4 \mathrm{ng} / \mathrm{ml}$ underwent TRUS guided prostate biopsy which revealed benign pathology. The mean serum PSA level had no significant difference across three BMI categories ( $p>0.05$ ) [Table-1].

No significant differences were observed in IPSS among BMI categories. Use of alpha blocker, and combination with 5 alpha reductase inhibitor (5-ARI) did not reveal any significant differences among BMI categories.

BMI had a significant impact on the PV. Mean PV was gradually larger with increasing BMI value (normal weight 33.02 cc; overweight $36.52 \mathrm{cc}$; obese $37.75 \mathrm{cc}$; $<0.001$ ) [Table-2].

BMI as continuous variables was analyzed using Spearman's correlation [Table 3]. BMI was found to have correlation with PV (rs= 0.132; $\mathrm{p}<0.001$ ) but not with PSA ( $\mathrm{rs}=0.039 ; \mathrm{p} 0.191$ ) and IPSS (rs= 0.013; p 0.760) [Figure-1].

\section{Discussion}

In our cross-sectional study of Indian population, BMI was found to have a significant positive association with prostate volume ( $\mathrm{rs}=0.132$ ). Obesity is the excessive fat accumulation in adipose tissue, not mere a passive energy depot, but acts like an endocrine organ secreting a number of mediators, including, adipokines, acute phase reactants, growth factors and numerous other cytokines [15]. In 1999, Colao et al conducted a study of acromegaly patients and age matched controls and found significantly higher prostate volume in the acromegalic patients than the control group [16]. The association between Insulin like growth factor-1 (IGF-1) and prostate volume was not found significant by Harman et al [17]. Sarma et al in 2001 in a population-based study of black men residing in Michigan, found a positive association between BMI and Insulin Like Growth Factor Binding Protein-3 (IGFBP-3) with prostate volume but no association between IGF-1 and prostate volume found [18]. Positive association between BMI and prostate volume in our study support cytokines mechanism which needs further molecular study. Clinical application of this association may illustrate the growth mechanism in benign prostatic hyperplasia or in the natural history of carcinoma prostate and may provide target for growth suppression and tumour control. In literature, studies describe positive or no significant association between BMI and prostate volume in different geographic and ethnic groups as shown in [Table-4] [18-22].

In our study, we observed no significant correlation between serum PSA value and BMI in male patients presenting with LUTS (rs=0.039). In literature PSA and BMI relationship had been studied in asymptomatic patients of different ethnic group and found inverse or no significant correlation [Table-4] [23-26]. The underlying mechanism for the BMI and serum PSA relationship is still unidentified. The hypothesis supporting inverse relationship include hemodilution and low androgen level. In obese patients due to high volume of distribution inverse correlation measured [27]. Obesity affects hormonal milieu by increasing free and total estradiol, lowering free and total testosterone and sex hormone binding globulin level [28]. This inverse result could be due to confounding; because high BMI patients usually had a high cholesterol level requiring statin therapy which leads to decrease in serum PSA level.

We observed no association between BMI and LUTS measured by IPSS, even on stratification by alpha blocker alone or combination with 5-ARI (rs=0.013). Kristal et al [29] and Lee et al. [30] observed positive correlation between BMI and LUTS while many other studies found no significant association between BMI and LUTS.

The strengthening features of our study include: (1) Prospective cross-sectional study where anthropometric measurements and blood sampling done on the first visit. (2) We studied the association of BMI with PV and serum PSA in patients having LUTS not in asymptomatic population, so including clinically coherent cohort. (3) To the author's knowledge this is the first prospective study from Indian ethnicity even from the South Asia region studying the association between BMI and PV 
Does Body Mass Index Have an Impact on Prostate Volume and Serum Prostate Specific Antigen? A Prospective Observational Study in Patients with Lower Urinary Tract Symptoms

Table-1: Characteristics of the 1100 Indian Men and the relationship between BMI, PSA and PV

\begin{tabular}{|c|c|c|c|c|}
\hline Clinical parameters & Total $\mathrm{N}=1100$ & $\begin{array}{l}\text { BMI }(17.50-22.99) \\
N_{1}(\%)=343(31.18)\end{array}$ & $\begin{array}{l}\text { BMI }(23.00-27.99) \\
N_{2}(\%)=638(58)\end{array}$ & $\begin{array}{l}\mathrm{BMI}>28.00 \\
\mathrm{~N}_{3}(\%)=119(10.82)\end{array}$ \\
\hline $\begin{array}{l}\text { Age(years); } \\
\text { Mean } \pm \text { SD }\end{array}$ & $58.18 \pm 10.36$ & $58.75 \pm 9.34$ & $57.63 \pm 10.90$ & $59.53 \pm 10.65$ \\
\hline PSA (ng/ml) & $1.93 \pm 1.79$ & $1.98 \pm 1.76$ & $1.87 \pm 1.78$ & $2.11 \pm 1.96$ \\
\hline IPSS (Median; IQR) & $10(7-14)$ & $11(6-18)$ & $10(6-12)$ & $10(8-14)$ \\
\hline PV (cc.) Mean \pm SD & $35.56 \pm 3.62$ & $33.02 \pm 3.15$ & $36.52 \pm 3.68$ & $37.75 \pm 3.94$ \\
\hline $\begin{array}{l}\text { Alpha Blocker n (\%) } \\
\text { Yes } \\
\text { No }\end{array}$ & $\begin{array}{l}180(16.34) \\
920(83.66)\end{array}$ & $\begin{array}{l}51(14.86) \\
292(85.14)\end{array}$ & $\begin{array}{l}115(18.03) \\
523(81.97)\end{array}$ & $\begin{array}{l}14(11.76) \\
105(88.24)\end{array}$ \\
\hline $\begin{array}{l}\text { Alpha + 5-ARI n (\%) } \\
\text { Yes } \\
\text { No }\end{array}$ & $\begin{array}{l}34(3.09) \\
1066(96.91)\end{array}$ & $\begin{array}{l}10(2.92) \\
333(91.08)\end{array}$ & $\begin{array}{l}18(2.82) \\
620(97.18)\end{array}$ & $\begin{array}{l}6(5.04) \\
113(94.96)\end{array}$ \\
\hline
\end{tabular}

BMI: Body Mass Index; PV: Prostate volume; PSA: Prostate Specific Antigen; IPSS: International Prostate Symptom Score; 5-ARI: 5-Alpha Reductase Inhibitor

Table-2: Stratified analysis of BMI groups demonstrating effect over prostate volume; Prostate Specific Antigen level and International Prostate Symptom Score

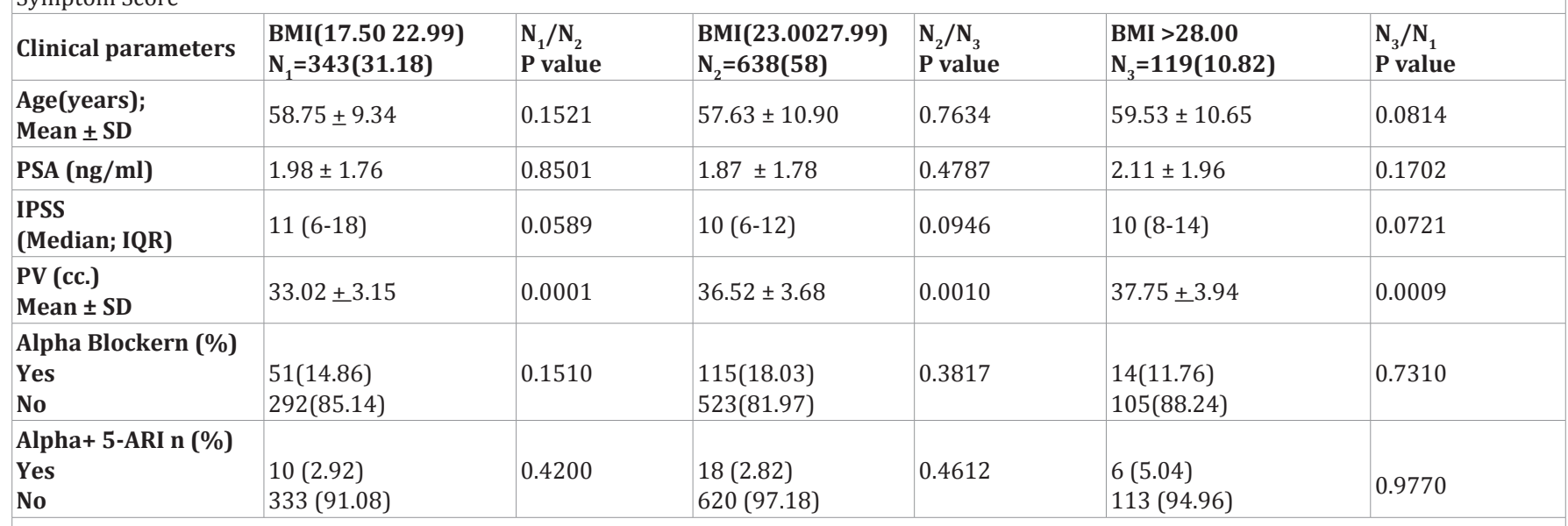

BMI: Body Mass Index; PV: Prostate Volume; PSA: Prostate Specific Antigen; IPSS: International Prostate Symptom Score; 5-ARI: 5-Alpha Reductase Inhibitor

Table 3: Spearman's correlations between body mass index; prostate volume; Prostate Specific Antigen and International Prostate Symptom Score

\begin{tabular}{|l|l|l|l|l|}
\hline \multirow{2}{*}{ BMI } & BMI & PV & PSA & IPSS \\
\hline \multirow{2}{*}{ PV } & & $0.132^{*}$ & 0.039 & 0.013 \\
\cline { 2 - 5 } & & $<0.001^{\#}$ & 0.191 & 0.76 \\
\hline \multirow{2}{*}{ PSA } & $0.132^{*}$ & & 0.68 & 0.178 \\
\hline \multirow{2}{*}{ IPSS } & 0.039 & 0.68 & 0.071 & $<0.001$ \\
\hline & 0.191 & 0.071 & & -0.004 \\
\hline & 0.013 & 0.178 & & 0.721 \\
\hline
\end{tabular}

BMI: Body Mass Index; PV: Prostate Volume; PSA: Prostate Specific Antigen; IPSS: International Prostate Symptom Score; ${ }^{*} r_{s}$ : Spearman's Correlation Coefficient; ${ }^{*}$ p: p-value

and serum PSA in patients having LUTS.

We identified certain limitations of our study. Being cross section observational nature of study, this study cannot institute cause and effect relationship. We used BMI as the only measure of obesity, which has its own limitation of classifying man with large muscle mass but less fat as obese or overweight.

\section{Conclusions}

In conclusion, we establish a positive correlation of BMI with prostate volume among Indian ethnic patients presenting with LUTS. We found no significant association of BMI with serum PSA and IPSS. To establish an underlying mechanism a further research at a molecular and genetic level as warranted.

\section{Acknowledgements}

I acknowledge the cooperation of residents of the Urology department of the King George medical university who participated in data collection and evaluation of the patient. We also appreciate the commitment and compliance of the patient who reported the required data.

\section{Ethical approval}

Ethical approval has been taken from Institutional Ethical Committee. 


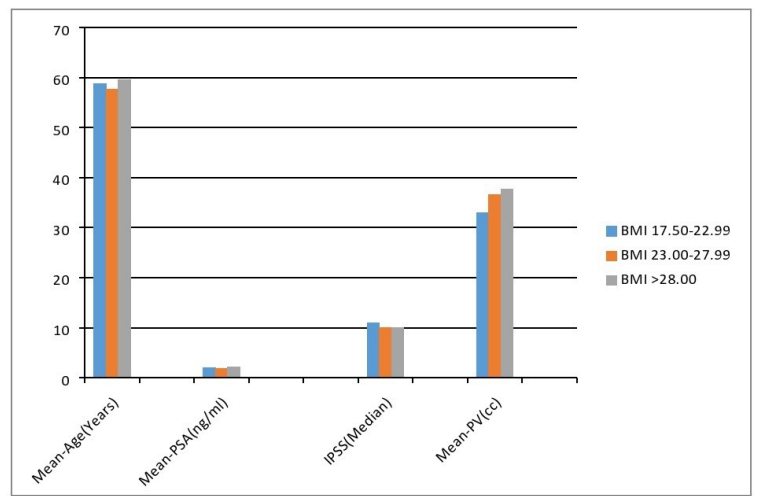

Figure 1: Relationship of PSA; IPSS and prostate volume among different BMI groups

Table 4: Summary of published studies on relationship with BMI; PV and PSA among different ethnic groups

Published studies on relationship between BMI and PV

\begin{tabular}{|l|l|l|l|l|}
\hline Reference & Ethnicity & $\begin{array}{l}\text { Type of } \\
\text { study }\end{array}$ & $\begin{array}{l}\text { Sample } \\
\text { size }\end{array}$ & $\begin{array}{l}\text { BMI/ PV } \\
\text { Relationship }\end{array}$ \\
\hline $\begin{array}{l}\text { Sarma et al } \\
\text { 2002 [26] }\end{array}$ & $\begin{array}{l}\text { Genesee } \\
\text { County, } \\
\text { Michigan } \\
\text { (American) }\end{array}$ & Case-control & 364 & Positive \\
\hline $\begin{array}{l}\text { Signorello et al. } \\
\text { 1999 [27] }\end{array}$ & $\begin{array}{l}\text { Greater Athens, } \\
\text { Greece }\end{array}$ & Case-control & 209 & NS \\
\hline $\begin{array}{l}\text { Dahle et al 2002 } \\
\text { [28] }\end{array}$ & Shanghai, China & & 502 & NS \\
\hline $\begin{array}{l}\text { Glynn et al 1985 } \\
\text { [29] }\end{array}$ & $\begin{array}{l}\text { Noterans Affairs } \\
\text { Aging Study } \\
\text { Boston }\end{array}$ & $\begin{array}{l}\text { Longitudinal } \\
\text { study }\end{array}$ & 2036 & Positive \\
\hline $\begin{array}{l}\text { Meigs et al 2001 } \\
\text { [30] }\end{array}$ & $\begin{array}{l}\text { Massachusetts } \\
\text { Male Aging }\end{array}$ & & 1709 & NS \\
\hline Study & The Baltimore & & & \\
\hline $\begin{array}{l}\text { Parson's et al. } \\
\text { Longitudinal }\end{array}$ & Prospective & 422 & Positive \\
\hline Study of Aging. & cohort study & & \\
\hline Published studies on relationship between BMI and PV \\
\hline Reference & Ethnicity & Sample size & $\begin{array}{l}\text { Mean } \\
\text { PSA }\end{array}$ & BMI/PSA \\
relationship
\end{tabular}

NS: Not significant; Positive- Significant positive association; InverseSignificant inverse association; BMI: Body mass index; PV: Prostate volume; PSA: Prostate Specific Antigen; IPSS; International Prostate Symptom Score

\section{References}

1. Lalitha K, Suman G, Pruthvish S, Mathew A, Murthy NS. Estimation of Time Trends of Incidence of Prostate Cancer -an Indian Scenario. Asian Pac J Cancer Prev. 2012;13(12):6245-6250.

2. Wei JT, Calhoun E, Jacobsen SJ. Urologic diseases in America project: benign prostatic hyperplasia. J Urol. 2005; 173(4):1256-1261.

3. Stroup SP, Palazzi-Churas K, Kopp RP. Trends in adverse events of benign prostatic hyperplasia (BPH) in the USA, 1998 to 2008. BJU Int. 2012;109(1):84-87. doi: 10.1111/j.1464-410X.2011.10250.x.

4. Mc Vary KT. BPH: epidemiology and comorbidities. Am J Manag Care. 2006;12(5 Suppl):S122-8.

5. McVary KT, Roehrborn CG, Avins AL, Barry MJ, Bruskewitz RC, Donnell $\mathrm{RF}$, et al. Update on AUA guideline on the management of benign prostatic hyperplasia. J Urol. 2011;185(5):1793-1803. doi: 10.1016/j. juro.2011.01.074

6. Bratt 0 , Lilja H. Serum markers in prostate cancer detection. Curr Opin Urol. 2015;25(1):59-64. doi: 10.1097/MOU.0000000000000128.

7. Jae Ouk Ahn, Ja hyeon ku. Relationship between serum prostatespecific antigen levels and body mass index in healthy younger men. Urology. 2006;68(3):570-574. doi: 10.1016/j.urology.2006.03.021.

8. Cornu JN, Cancel-Tassin G, Cox DG, Roupret M, Koutlidis N, Bigot $\mathrm{P}$, et al. Impact of Body Mass Index, Age, Prostate Volume, and Genetic Polymorphisms on Prostate-specific Antigen Levels in a Control Population. Eur Urol. 2016;70(1):6-8. doi: 10.1016/j. eururo.2016.01.027.

9. 'Global, regional, and national prevalence of overweight and obesity in children and adults during 1980-2013: A systematic analysis for the Global Burden of Disease Study 2013'. Lancet. 2015;386(9995):743800. doi: 10.1016/S0140-6736(15)60692-4.

10. Freedland SJ, Aronson WJ, Kane CJ, Presti JC Jr, Amling CL, Elashoff $\mathrm{D}$, et al. Impact of obesity on biochemical control after radical prostatectomy for clinically localized prostate cancer: a report by the Shared Equal Access Regional Cancer Hospital database study group. J Clin Oncol. 2004;22(3):446-453.

11. Rohrmann S, Smit E, Giovannucci E, Platz EA. Associations of obesity with lower urinary tract symptoms and noncancer prostate surgery in the Third National Health and Nutrition Examination Survey. Am J Epidemiol. 2004;159(4):390-397.

12. Park JH, Cho BL, Kwon HT, Lee CM, Han HJ. Effect of body mass indexand waist circumference on prostate specific antigen and prostate volume in a generally healthy Korean population. J Urol. 2009;182(1):106110; discussion 110-1. doi: 10.1016/j.juro.2009.02.130.

13. Laven BA, Orsini N, Andersson SO, Johansson JE, Gerber GS, Wolk A. Birth weight, abdominal obesity and the risk of lower urinary tract symptoms in a population based study of Swedish men. J Urol. 2008;179(5):1891-1895; discussion 1895-6. doi: 10.1016/j. juro.2008.01.029.

14.WHO Expert Consultation. Appropriate body-mass index for Asian populations and its implications for policy and intervention strategies. Lancet. 2004;363(9403):157-163.

15. Karastergiou K, Mohamed-Ali V. The autocrine and paracrine rolesn of adipokines. Mol Cell Endocrinol. 2010 ;318(1-2):69-78. doi: 10.1016/j.mce.2009.11.011.

16. Colao A, Marzullo P, Spiezia S, Ferone D, Giaccio A, Cerbone G, et al: Effect of growth hormone $(\mathrm{GH})$ and insulin-like growth factor I on prostate diseases: an ultrasonographic and endocrine study in 
acromegaly, GH deficiency, and healthy subjects. J Clin Endocrinol Metab. 1999;84(6):1986-1991.

17. Harman SM, Metter EJ, Blackman MR, Patricia KL, Ballentine Carteret H. Serum levels of insulin-like growth factor I (IGF-1), IGF-II, IGFbinding protein-3 and prostate-specific antigen as predictors of clinical prostate cancer. J Clin Endocrinol Metab. 2000;85(11):42584265.

18. Sarma AV, Jaffe CA, Schottenfeld D , Dunn R, Montie JE , Cooney KA, et al. Insulin-like growth factor-1, insulin-like growth factor binding protein-3, and body mass index: clinical correlates of prostate volume among black men. Urology. 2002;59(3):362-367. doi:10.1016/S00904295(01)01546-1.

19. Signorello LB, Tzonou A, Lagiou P, Samoli E, Zavitsanos X, Trichopoulos D. The epidemiology of benign prostatic hyperplasia: a study in Greece. BJU Int. 1999;84(3):286-291.

20. Dahle SE, Chokkalingam AP, Gao YT, Deng J, Stanczyk FZ, Hsing AW Body size and serum levels of insulin and leptin in relation to the risk of benign prostatic hyperplasia. J Urol. 2002;168(2):599-604.

21. Glynn RJ, Campion EW, Bouchard GR, Silbert JE. The development of benign prostatic hyperplasia among volunteers in the Normative Aging Study. Am J Epidemiol. 1985;121(1):78-90.

22. Meigs JB, Mohr B, Barry MJ, Collins MM, McKinlay JB. Risk factors for clinical benign prostatic hyperplasia in a community-based population of healthy aging men. J Clin Epidemiol. 2001;54(9):935-944.

23. Kim YJ, Han BK, Hong SK, Byun SS, Kim WJ, Lee SE. Body mass index influences prostate-specific antigen in men younger than 60 years of age. Int J Urol. 2007;14(11),1009-12.
24. Ando R, Nagaya T, Hashimoto Y, Suzuki S, Itoh Y, Umemoto Y, et al. Inverse relationship between obesity and serum prostate-specific antigen level in healthy Japanese men: a hospital-based cross-sectional survey, 2004-2006. Urology. 2008;72(3):561-5. doi: 10.1016/j. urology.2008.04.008.

25. Chia SE, Lau WK, Chin CM, Tan J, Ho SH, Lee J, et al. Effect of ageing and body mass index on prostate-specific antigen levels among Chinese men in Singapore from a community-based study. BJU Int 2009;103(11):1487-1491. doi: 10.1111/j.1464-410X.2008.08246.x.

26. Werny DM, Thompson T, Saraiya M, Freedman D, Kottiri BJ, German $\mathrm{RR}$, et al. Obesity is negatively associated with prostate-specific antigen in U.S. men, 2001-2004. Cancer Epidemiol Biomarkers Prev. 2007;16(1),70-76.

27. Ohwaki K, Endo F, Muraishi O, Hiramatsu S, Yano E. Relationship Between Prostate-specific antigen and hematocrit: Does hemodilution lead to lower PSA concentrations in men with a higher body mass index? Urology. 2010;75(3):648-652. doi: 10.1016/j.urology.2009.06.099.

28. Giovannucci E, Rimm EB, Chute CG, Kawachi I, Colditz GA, Stampfer MJ, et al: Obesity and benign prostatic hyperplasia. Am J Epidemiol. 1994;140(11):989-1002.

29. Kristal AR, Arnold KB, Schenk JM, Neuhouser ML, Weiss N, Goodman P, et al. Race/ethnicity, obesity, health related behaviors and the risk of symptomatic benign prostatic hyperplasia: results from the prostate cancer prevention trial. J Urol. 207;177(4):1395-4000; quiz 1591.

30. Lee RK, Chung D, Chughtai B, Te AE, Kaplan SA. Central obesity as measured by waist circumference is predictive of severity of lower urinary tract symptoms. BJU Int. 2012;110(4):540-554. doi: 10.1111/j.1464-410X.2011.10819.x. 